\title{
An Australian perspective on Standards-Based Education, Teacher Knowledge and English as an Additional Language Students
}

\begin{abstract}
In this article, I present an Australian perspective on the issue of standards-based education and the place of English as an Additional Language (EAL) students who are working within mainstream schools. I begin with an overview of the various standards documents that impact the lives of teachers and their students in mainstream Australian schools, before turning to a wider discussion of the kind of knowledge required of teachers in their work with EAL students. I draw on research that my colleagues and I completed over an extended period of time to address questions about teacher knowledge and specifically to address the domains of knowledge required for the effective design and implementation of programs with EAL students. I argue that while standards can and do play an important role in legitimizing knowledge, in themselves they cannot provide the depth of theoretical and professional knowledge that is required of teachers in the planning and implementation of effective teaching practices that both challenge and support their students, including their EAL students.
\end{abstract}

\section{Introduction}

Australia, like other developed countries, has significant numbers of recently arrived and established immigrants within its population. General estimates are that $20 \%$ to $25 \%$ of school students in Australia are from non-English speaking 
backgrounds, although in New South Wales (where I live), 30\% of students are from non-English-speaking backgrounds (CESE, 2012). Some of these students were born in the country but spoke little English prior to beginning school; others have arrived more recently and are in various stages of learning English. Many require specific supports in their ongoing learning of academic English.

While there is evidence that some English as an Additional Language (EAL) students are doing well at school (Thompson, de Bortoli, \& Buckley, 2013), such success is uneven, and often correlates with students' socioeconomic backgrounds and previous educational experiences. In addition, the latest round of Programme for International Student Assessment (PISA) results provides evidence that overall educational achievement in Australian schools, in relation to other developed countries, has fallen (Thompson et al., 2013). While a complex range of factors, in Australia as in other countries, impact any measure of school achievement, the PISA results have intensified debates in Australia about ways of ensuring that educational achievement for all students is "the best in the world". There is thus considerable focus on ways of achieving educational success, on the need to improve "teacher quality", and on how we measure educational success. In this context, discussion of standards-based education is highly relevant.

Although the profile of standards here is somewhat different from that in America or other parts of the world, it is still significant. In various guises, standards have been part of the Australian education scene in both school and adult education for many years (Nunan, 2007). However, for those concerned with school education, there are ongoing questions about the status of educational standards, and about assumptions (evident especially at a political level) that standards can adequately reflect educational achievement. Although there is limited literature on the topic, 
debates have highlighted concerns that over-reliance on standards can subsume a broader emphasis on the kind of teacher knowledge required for effective program design and implementation, and that such over-reliance could actually work against educational achievement. For those concerned with the education of students from culturally and linguistically diverse backgrounds, such questions assume a greater significance, particularly regarding ways in which such students are positioned in relation to standards and the extent to which standards that have been designed for mainstream students can reflect the educational needs and achievement of diverse students, including EAL students.

In addressing these concerns, I begin with an overview of the various standards documents that impact teachers and students in mainstream Australian schools.

\section{Standards-based Education in the Australian Context}

In Australia we are awash with standards. Within schools, some of these standards are directed at students' learning and learning outcomes; others focus on teachers and the kind of professional abilities and knowledge required of successful teachers; and still others address levels of professional qualifications in teacher education. The status of various standards is further complicated by the somewhat politicised nature of education in Australia. Standards compulsory under one government may change with a new government, or because of overlapping domains of control in education between national and state governments. The net outcome is that Australia's standards situation is complex and often unstable.

\section{Standards for Students' Learning}

Standards relevant to students' learning are addressed primarily through mandatory curriculum documents. While each Australian state has traditionally had 
its own curriculum, a recent initiative towards development of a national curriculum has been particularly significant.

The national Australian Curriculum (ACARA, 2012a) has been developed with the aim of ensuring greater consistency between states in educational priorities and outcomes. Currently, curriculum documents in the disciplines of English, mathematics, science and history for Kindergarten to Year 10 have been completed, with work on other discipline documents, as well as senior years (Years 11 and 12) for all disciplines, at various stages of completion. In addition to specifying content knowledge and Achievement Standards for each discipline and for each year of schooling, each Australian Curriculum document specifies a range of General Capabilities and Cross Curriculum priorities that aim to "add depth and richness to students' learning" (ACARA, 2012b, p.12). As one would expect in a national Curriculum, overall goals specify high ideals of excellence in education, while goals within specific subject documents emphasise intellectual depth and quality.

There are a number of features in this Australian Curriculum initiative of particular significance for EAL students. First, there is a strong emphasis on equity and access for all students. A guiding principle for the development of the Australian Curriculum (ACARA, 2009, p. 8) states:

One important lesson learned from past efforts to overcome inequality is that an alternative curriculum for students regarded as disadvantaged does not treat them equitably. It is better to set the same high expectations for all students and to provide differentiated levels of support to ensure that all students have a fair chance to achieve those expectations. 
Thus all students, including EAL students, are expected to meet the same high educational standards; and all students are expected to reach the same student Achievement Standards for each subject and year of schooling.

Second, there is acknowledgement of the need for differentiated support to enable diverse students to participate fully in the Australian Curriculum. While emphasising similar aims for all students, documents for each discipline state that EAL students "require additional time and support, along with informed teaching that explicitly addresses their language needs, and assessments that take into account their developing language proficiency" (ACARA, 2012b, p. 11). In recognition of this, the Australian Curriculum is accompanied by a support document English as an Additional Language or Dialect: Teacher Resource (ACARA, 2011) describing expected learning progressions for students with Beginning, Emerging, Developing and Consolidating levels of English across stages of schooling from Kindergarten to Year 10. This document aims to guide teachers in monitoring EAL students' learning progression in listening, speaking, reading and writing, and to assist them to map students' progression onto Curriculum-specified standards. This document now supersedes The ESL Scales (Curriculum Corporation, 1994) that were designed to assist teachers to analyse their EAL students' language skills, and to map their progress against the demands of mainstream curricula.

A further positive feature of the Australian Curriculum initiative for EAL students is its explicit focus on language and knowledge about language within the English discipline document (ACARA, 2012b). Curriculum content in English is built around three interconnecting Strands of Language, Literature and Literacy. The Curriculum prioritises students' use of language (through the Literature and Literacy strands); but in addition, it gives status to knowledge about language and literacy 
(through the Language strand). The English document thus places language, literacy, and knowledge about language at the discipline's centre.

At a broad level, with its goals of equitable access and explicit rejection of a modified or alternative curriculum, the Australian Curriculum positions EAL students as equal with their peers (although without explicit recognition of students' first languages - see Flores \& Schissel, this issue). In addition, the priority accorded to language and literacy development, and the level of detail of knowledge about language in the English document have positive implications for educating EAL students. However, as is often the case, the process of development of the Australian Curriculum has been complex and at times highly political. Despite overall agreement on the value of a national Curriculum, some states in Australia have resisted aspects or delayed implementation, and thus some individual state curricula still exist alongside the Australian Curriculum. In addition, our recently elected conservative national government has just announced a review of the Australian Curriculum. This announcement, apparently primarily to mark a departure from work of the previous government, has occurred at a time when the Curriculum is just beginning to be implemented systematically at a national level, and it has generated considerable concern and uncertainty amongst educators.

Also of significance to standards of students' learning are national high-stakes assessment procedures. The longest standing of these are final Year 12 examinations conducted by each state. Outcomes from examinations, such as the New South Wales Higher School Certificate and the Victorian Certificate of Education, determine students' access to tertiary study and other post-school courses. EAL students compete with their English-speaking peers in these examinations, and while some 
achieve high levels of academic success, others are disadvantaged by challenges they face in learning through English while also learning English.

Other high-stakes assessment procedures include the National Assessment Program - Literacy and Numeracy (NAPLAN, 2011). This program consists of tests of reading, writing, language conventions (spelling, grammar, punctuation), and numeracy. It is administered nationally and annually to all students in Years 3, 5, 7 and 9. EAL students who have been in the country for less than one year may be exempted from these tests, although this exemption is not automatic and students who wish to participate are encouraged to do so. EAL students who do participate are assessed in the same way as their English-speaking peers.

While NAPLAN had been used in schools for a number of years to provide diagnostic feedback on students' skills in literacy and numeracy, its status changed significantly in 2010 when students' outcomes for each school became a key component of the MySchool website (a national government website providing information to families and community members about individual schools). Although not primarily intended to provide comparative standards, the inclusion of students' NAPLAN results for each Australian school has in fact done just this. Currently, although funding for schools is not tied to NAPLAN outcomes, there is considerable resulting public and government pressure on students and their teachers to score well on NAPLAN tests. There has also been considerable resulting controversy around the use of NAPLAN results to rank schools. Apart from final school examinations, NAPLAN is the assessment procedure that receives most public and professional focus in the Australian school context.

\section{Standards for Teachers}


Other standards in the Australian context address teacher and teaching quality. An early initiative was the set of Teacher Standards developed by the Australian Council of TESOL Associations (ACTA, 2004). These consisted of nine standards clustered under headings of Dispositions toward TESOL; Understandings about TESOL; and Skills in TESOL. Despite ACTA's position as the key professional organisation for TESOL in Australia, the status of these standards remained ambiguous, and they were superseded by other initiatives aimed more generally at providing standards for all teachers. Currently, ACTA standards (ACTA, 2013) are being updated and redesigned to provide greater consistency in format with recent national teacher standards initiatives, thereby assisting teachers to map the EALoriented detail of ACTA standards onto national teacher standards.

The development of national teacher standards has been of considerable significance in Australia. The National Professional Standards for Teachers aim to “provide a public statement of what constitutes teacher quality” (AITSL, 2011, p. 2). These comprise seven standards grouped into categories of Professional Knowledge, Professional Practice and Professional Engagement. They outline what teachers of any discipline should know and be able to do. These National Standards have been endorsed by various Australian state departments of education and adopted as their own, although prior to this, many states had their own standards. For example, NSW is transitioning from its own Standards to the National Professional Standards, although currently two sets of Standards coexist.

Knowledge required to recognise strengths and needs of EAL students is addressed to varying degrees in the Teacher Standards documents that exist across Australia. As indicated, EAL students were the specific focus of the ACTA (2004) initiative. Although these standards did not have a formal status within school systems, 
their emphasis on the nature of teacher knowledge required to address the specific needs of linguistically and culturally diverse students is reflected in part within the National Professional Standards for Teachers (AITSL, 2011). Here a number of elements within specific standards are directly relevant to EAL students (Barnett, 2012). The most obvious of these is within Standard 1: Know students and how they learn, (AITSL, 2011, p. 8) where teachers are required to be able to design and implement teaching strategies responsive to learning strengths and needs of students from diverse linguistic, cultural, religious, and socioeconomic backgrounds (standard 1.3). However, other elements are also relevant to EAL students as they require teachers, for example, to be able to provide: differentiated and engaging learning strategies (standards $1.5 ; 2.1$ ); support for students' language and literacy development (standard 2.5); and inclusive and positive interactions to engage and support all students (standard 4.1). Thus the knowledge required of teachers to address EAL students' specific strengths and needs is recognized, at least to some extent, within a broader framework of the kind of knowledge and skills required of any teacher who needs to be able to work effectively with diverse groups of students.

\section{Standards for Teacher Education}

For those in teacher education, there is yet another relevant set of standards The Australian Qualifications Framework (AQF, 2013). This Framework aims to provide a single national overview of all Australian education and training qualifications. It consists of a "taxonomic structure of levels and qualification types, each of which is defined by a taxonomy of learning outcomes" (AQF, 2013, p. 11). Levels and qualifications are listed from Level 1 (Certificate 1, which aims to develop basic knowledge and skills to enable students to proceed with further training) to Level 10 (the equivalent of a Ph.D.). Level 7 equates to a bachelor's degree, Level 8 
to a graduate certificate or diploma, and Level 9 to a master's degree. Learning outcomes for each level are specified in terms of what graduates are expected to know, understand, and be able to do as a result of learning, and in terms of dimensions of knowledge, skills, and the application of knowledge and skills. Specialist TESOL courses, like other teacher-education courses, are expected to comply with this Framework. Depending on the nature of the TESOL course, this will typically mean complying with Level 8 or 9 requirements.

In sum, the "standards situation" in Australia is complex, with the result that negotiating various standards requirements can be challenging. School-teachers are required to follow mandatory national and/or state curriculum documents in planning and implementation of their classroom programs. They are also under pressure to ensure students are prepared for various assessment procedures, particularly final school examinations and NAPLAN tests. Currently, Achievement Standards specified within the Australian Curriculum are unrelated to NAPLAN test results, and students are required to meet both sets of standards. In addition, to maintain their ongoing professional accreditation, and to advance their careers, teachers must comply with mandatory national and state teacher and teaching standards.

For those working in teacher education, the situation is similarly complex. For example, as part of the recent reaccreditation of a master's in TESOL at an Australian university, course designers needed to take account of the Australian Qualifications Framework and to position the course in relation to Level 9 (master's level qualifications) taxonomies of specified knowledge, skills and application; they needed to take account of the Australian Curriculum, especially of the subject English, and the curriculum content and Achievement Standards specified in this document; they needed to take account of national and state institutes of teachers and their 
specifications of standards; and because this was a TESOL course, they also needed to take account of ACTA standards.

\section{Teacher Knowledge: An Alternative Perspective to Standards}

With the plethora of standards in Australia, the question arises of how useful they can be in guiding education of EAL students in mainstream schooling. As even this brief overview demonstrates, the current array of standards can be difficult to negotiate and subject to political vagaries and whims. In addition, as Wells (1999a) has argued, the "language" of educational administration (including standards) is different from that of teaching and research, and informed by different theories of knowledge and concerns. Such arguments suggest that a more robust approach to the educational needs of EAL students, and one that has gained considerable attention in the educational literature, is via articulation of the theoretical and professional knowledge required of teachers in working with students.

Concern with the kind of professional knowledge required of teachers has a substantial history. Within the TESOL field, the nature of the relationship between content and pedagogical knowledge has generated ongoing, substantial discussion (Shulman, 1987; Freeman, 2002), as has the relationship between pedagogical content and knowledge of language (Bunch, 2013). Debates about teacher knowledge are shaped by underlying theories of knowledge, language, and learning. The argument, made by Lo Bianco \& Freebody (1997, p. 35) some years ago, is especially relevant. They contend strong teachers need to develop their own "strong pedagogical framework". Such a framework is based on substantial theoretical and pedagogical understandings and provides a basis for ongoing professional learning and informed critique of educational innovations. It enables teachers to make theoretically informed decisions in program design and implementation. In the Australian context, it also 
provides the necessary depth of knowledge and understanding to enable teachers to negotiate the complex and at times competing demands of standards-based education, and to resist some of the more unhelpful political interventions as appropriate.

The question then, in relation to the education of EAL students, is what kind of knowledge informs development of a strong pedagogical framework? I approach this question via research my colleagues and I have conducted over a period of more than 10 years (Hammond \& Gibbons, 2005; Hammond, 2008; Gibbons, 2008;

Michell \& Sharpe, 2005). I draw on details of the research as a way of approaching the kind of knowledge required of teachers in the development of strong pedagogical frameworks. My purpose is not to provide exemplary models of program planning or teaching, but to use the discussion to tease out categories representing the minimal knowledge required by teachers as a basis for high-quality pedagogical practices.

\section{Investigating High Challenge, High Support Programs for EAL Students}

Our research involved working with teachers in schools where $60 \%$ or more of the student population were EAL students. In such schools, many students also experience poverty and varying levels of social disruption, and in some, the general expectations of academic outcomes are low (Johnston \& Hayes, 2008). Our aim was to challenge prevailing views that students in these "difficult" schools were unlikely to achieve high levels of educational success. Our focus was on students who were beyond the initial (and obvious) stages of learning English and who were located in mainstream classes. Such students, while usually quite fluent in oral conversational English, typically required ongoing support in developing academic English (Cummins, 2000; Gibbons 2002). Such students are also sometimes "invisible" in that their specific needs for English support can be mistaken for lack of educational ability. 
We invited experienced classroom and specialist EAL teachers in six schools, who were team teaching in middle years of schooling (Years 5-8), to work with us to plan and implement programs characterised by dimensions of high challenge and high support. The research was informed by Vygotskian theories of learning (Vygotsky, 1978; Mercer, 1994; Wells, 1999b) and the assumption that learning occurs primarily in collaborative social interactions between learners and more knowledgeable others. It was also informed by systemic functional linguistics, with its emphasis, via register and genre theory, on the functional interrelationship between text and context (Halliday, 1978; Christie \& Martin, 2007; see also Palincsar \& Schleppegrell, this issue). The research itself involved cycles of professional and theoretical input, collaborative program planning, documentation and analysis of the impact of programs, and shared reflection on teaching practices. Documentation of programs involved video recording of lessons, collection of students' written texts, and collection of key curriculum and teaching resources. Our starting point was broad agreement amongst the research team (of researchers and teachers) that learning environments characterised by high challenge and high support were most likely to promote effective learning, but also recognition that the major task was to articulate what such learning environments actually looked like in practice. Key questions addressed in the research were: what did teachers need to know to plan for and enact dimensions of high challenge and high support in ways that recognised their EAL students' needs; and what teaching practices were required to bring them to life?

The following sections address such questions through a discussion of outcomes from the research.

\section{Dimension 1: High Challenge}


A major part of the rationale for our research was the argument that EAL students with access to high-challenge programs can and do achieve educational success, providing they also have access to appropriately targeted and differentiated support. There is strong research evidence to support this argument. Newmann and his associates (Newmann, Marks, \& Gamoran, 1996), for example, provide evidence that programs characterised by high intellectual challenge impact positively on the educational achievement of all students, including EAL students, and that as a result of engagement with high-challenge programs, the equity gap is reduced. Such outcomes are consistent with the extensive literature on teacher expectations that indicates all students, including EAL students, achieve higher educational outcomes when teachers' expectations are high (Mehan, 1992). The initial phase of our own research also highlighted the close relationship between high-challenge programs and high expectations (Hammond, 2008).

As indicated, our research team accepted the premise that high-challenge programs were essential for students' educational achievement. Our aim was to plan and implement programs that would ensure students had access to substantial curriculum knowledge, but in addition, were able to engage at deep levels with this knowledge and recognise the significance of key concepts in the world beyond school. In such programs students would have access to "opportunities to engage in higher order thinking, transform information, engage in inquiry-oriented activity, and construct their own understandings through participating in substantive conversations with others" (Gibbons, 2008, p. 157). The task was to articulate what such programs looked like in the lived curriculum, as teachers and students engaged in day-to-day learning. 
To address this task, first and perhaps most obviously, teachers required knowledge of their disciplines (of history, science, geography, mathematics). And indeed our teachers saw such knowledge as essential to being effective teachers. However, discipline knowledge was clearly not enough. In addition, teachers' required at least an understanding of the nature of intellectual challenge, and of ways of planning and implementing programs that enacted this understanding. Intellectual challenge is complex. In addressing this issue, we began with initiatives that have focused in various ways on the notion of "quality teaching" (Productive Pedagogies, 2002; Quality Teaching Initiative, NSW, 2003). These initiatives share descriptors of intellectual quality that include deep understanding of substantive concepts, the active construction of knowledge by students, the use of higher-order thinking involving manipulation and transformation of knowledge, and substantive conversations and interactions around key curriculum concepts. As Gibbons (2008) explains when writing about this aspect of the research, we aimed to describe the nature of intellectual challenge and intellectual quality by defining some of the major practices embedded in tasks and activities in which students were engaged, and to describe ways teachers supported students to be successful participants in these activities. This approach was in line with the sociocultural orientation of the research that positioned teachers and students as active participants in collaborative learning processes.

\section{Illustrating High Challenge in the Classroom}

Such understandings of the nature of intellectual challenge informed ways in which teachers planned and implemented "high-challenge" programs. More specific "tools" available from quality teaching initiatives, as well as from the broader literature on curriculum development, also informed planning processes. To illustrate, 
the following discussion draws on examples from two science programs - one from an upper-primary Year 6 class where students were engaged in the study of Vision; the other from a lower-secondary Year 7 class where students were engaged in the study of Matter: Elements, Compounds and Mixtures. In both programs, the sequence of lessons developed during the research met mandatory curriculum requirements regarding content and assessment procedures. As indicated earlier, my purpose in highlighting these programs is not as models, but to foreground the kind of teacher knowledge that informed their planning and implementation.

Following their initial analysis of students' needs and curriculum demands, teachers in all research schools began their processes of planning for high-challenge programs by working with the tools of Essential Questions (Wiggins \& McTighe, 2005) and Rich Tasks (New Basics, 2001). Essential Questions can be defined as providing relevant and genuine inquiry into big ideas and core curriculum content; as provoking deep thought and new understandings; and as requiring students to consider alternatives and weigh evidence. Key principles of Rich Tasks are that they should be representative of an educational outcome of demonstrable and substantial intellectual and educational value; they should be problem-based, with relevance beyond the school program; they should be recognisable by educators, families, and community stakeholders as being significant and important; and where possible they should be cross disciplinary (New Basics, 2010, p. 7). Examples, in Table 1, from the Year 6 and Year 7 Science programs illustrate these tools.

(insert Table 1 here)

For teachers already familiar with the notion of program and unit goals, the significance of Essential Questions lay, not in any resulting difference in curriculum knowledge, but rather, in an epistemological shift in how students might engage with 
that knowledge. By posing Essential Questions as questions, the teachers reported they were pushed to clarify, in ways they had not previously experienced, what they regarded as key understandings and essential curriculum knowledge. The shift was from a focus on the curriculum content that students would be required to "cover" in a program, to clarification of the key curriculum understandings and concepts that students needed to engage with (for a similar focus on conceptual understanding, see Koelsch, Chu, \& Rodriguez Banuelos, this issue). The related underlying theoretical shift was from teaching as the transmission of information, to teaching as a collaborative social process where knowledge is constructed between participants in the process (Hammond \& Gibbons, 2005).

In addition to Essential Questions, teachers worked with the notion of Rich Tasks. Neither the teachers nor researchers found the process of designing Rich Tasks easy. Planning a Rich Task first required sound knowledge of discipline content. It required close analysis of students' existing relevant background and curriculum knowledge, including their language and literacy skills, and an analysis of curriculum demands. It required decisions about where students should be by the end of the program. Such decisions needed to reflect high expectations on behalf of the teacher, but they also needed to be realistic. The task itself needed to draw together understandings and skills students had developed across the whole program in ways that provided them with opportunities to address substantial intellectual problems. And on top of that, it needed to engage students' imagination and enthusiasm. The Rich Tasks developed during our research varied somewhat in the extent to which they successfully met these criteria. However, teachers in all research schools reported that implementation of Rich Tasks resulted in higher-than-usual levels of student engagement, and provided increased intellectual push in their programs. 
The identification of Essential Questions and the designing of a Rich Task provided both a start and end point in the program-planning process, and a clear path between what students already knew and could do, and what they needed to know and do by the end of the unit of work. Our teachers reported these tools enabled an orientation to learning that was focused, that was problem-oriented, that opened opportunities for genuine inquiry and deep thought, and that was engaging. Significantly, teachers shared details of both Essential Questions and Rich Tasks with students during the implementation of programs, providing opportunities for metacognitive reflection on purposes and directions of learning, and also for discussion of the significance of key concepts for learning and knowledge in the broader world.

In sum, our research indicated that the teacher knowledge required to plan and implement programs characterised by high challenge, required at least the following:

- knowledge of the relevant discipline;

- theoretical understandings of learning;

- $\quad$ an understanding of the nature of intellectual challenge;

- ability to analyse students' existing knowledge (of curriculum knowledge and of language and literacy skills); and

- tools to assist and enable effective planning for high challenge.

\section{Dimension 2: High Support}

While we considered the first dimension of equitable educational access to be the availability for all students of high-challenge programs, the second dimension was high support. In our research, we saw the task of providing high support as follows:

- how to support students to build knowledge and understanding of the curriculum content required for completion of a Rich Task; 
- how to support students to develop the necessary skills and language and literacy abilities needed to complete the Rich Task.

The question then is what do teachers need to know in order to plan programs that provide high support for their EAL students. We addressed this question via concepts of Backward Mapping and scaffolding.

Having worked with Essential Questions and Rich Tasks to identify start and end points in program planning, the teachers used the concept of Backward Mapping (Wiggins \& McTighe, 2005) to begin identifying the understandings, concepts and skills students needed to work between these points. Backward Mapping is not new. For us, its value lay in assisting teachers to tighten their planning processes. Teachers (and researchers) were pushed to identify specific details of the knowledge and skills students would need to complete the Rich Task, and then to work backwards to select and sequence tasks that would enable students to build on what they knew to develop further relevant understandings and skills required for completion of the Rich Task.

Teachers also worked with the notion of scaffolding (Mercer, 1994; Wells, 1999b; Gibbons, 2002; 2009). Despite the ubiquitous nature of this metaphor in educational literature, it captures the nature of the support needed to enable students, including EAL students, to develop a deep understanding of high-challenge educational concepts. For us, the sociocultural constructs, including Vygotsky's (1978) notion of the zone of proximal development, that underpin scaffolding provided a strong theoretical basis for identifying pedagogical strategies necessary for effective support. Key elements included the role of more knowledgeable others (primarily teachers in our case) in supporting and mediating students' learning, with the understanding that such support is temporary - as students' knowledge and skills develop, the support is withdrawn, so that responsibility for learning is handed over to 
students (Mercer, 1994). Key elements also included recognition of the importance of language in mediating learning and the importance of classroom interactions between teachers and students (Gibbons, 2002; see also Verplaetse, this issue). While the notion of scaffolding has informed the work of many, our additional task was to articulate what scaffolding looked like in the unfolding interactions that occurred between teachers and students within and between lessons.

In the process of analysing lessons, we needed to distinguish different levels of scaffolding. We concluded, as have others (van Lier, 1996), that scaffolding involves teachers' abilities to plan, select, and sequence tasks in their programs in response to the different levels and abilities of diverse students. It also comprises the ability to respond to the teachable moment: that is scaffolding is located at both the macro and micro levels of teaching (Hammond \& Gibbons, 2005). We therefore made a distinction between the designed-in scaffolding that occurs at the macro level of program planning, and the contingent scaffolding that is provided within each lesson in the moment-by-moment unfolding of classroom interactions (Michell \& Sharpe, 2005).

\section{Illustrating High Support in the Classroom}

The Year 6 Science program, introduced earlier, provides an illustration of how teachers drew on notions of Backward Mapping and scaffolding to design in high levels of support for students. A feature of this support was the resulting access to "message abundancy" (Gibbons, 2009, p. 156). The term message abundancy was introduced by Gibbons to refer to ways of providing students with access again and again to similar messages or concepts, via different modes of meaning. Message abundancy thus ensures that students who may not understand a concept the first time it is introduced, can visit and revisit the same concept via a range of activities and a 
range of semiotic modes, including, for example, hands-on activities, visual support, group discussion, IT support, reading tasks, written charts and so on. This concept is illustrated in Table 2 by a short sample of tasks from the Year 6 Science program. Insert Table 2 here

The individual tasks selected in this science unit were not unusual - each of these tasks could commonly be found in other science programs. The inclusion of whole-class, group, and individual activities was also not unusual. Of more significance was the systematic way in which tasks were sequenced to facilitate and support learning. As Table 2 shows, key concepts were typically introduced in wholeclass activities and then reinforced in group and individual activities. While all students were expected to engage with key curriculum concepts, systematic shifts between group and individual tasks enabled teachers to provide high support that was differentially targeted to address specific needs of different groups of students within the class. The sequencing of tasks also enabled progressive handover of responsibility of learning to students.

Additionally, the sequencing of tasks ensured students had access to high levels of message abundancy. They were able to take and make meaning from physical hands-on manipulation of objects, teacher-student explanations, peer discussions, wall charts that reminded them of the meaning of key scientific terms, written proformas that structured their actions and responses, and visual support provided by various educational resources. For EAL students, such access to message abundancy enabled them to engage with educational concepts while having time to visit and revisit the English language that was necessary for their developing understanding, and for their abilities to talk, read, and write about scientific concepts. 
A further major feature in the design of the Year 6 Unit, and of other research programs, was the embedding of academic-language development within the teaching of science. As the students learned science, they learned to "talk science" (Lemke, 1990). I discuss this feature in some detail in the following section.

To summarise thus far, our research suggests that the kind of knowledge required by teachers to provide "high support" programs includes at least:

- theoretical understandings of learning;

- an extensive knowledge of students and where they "are at" in terms of curriculum understandings and language and literacy skills;

- understandings of assessment procedures and the ability to undertake detailed analyses of students' conceptual and language abilities and analyses of the demands of curriculum;

- $\quad$ an extensive repertoire of teaching activities and strategies; and

- the ability to draw on that repertoire of teaching activities and strategies to select and sequence tasks in response to needs of students and demands of the curriculum (and in response to Essential Questions and Rich Task).

\section{Dimension 3: Supporting Academic Language and Literacy Development}

The most obvious area of need for EAL students in mainstream education is support in their academic English language and literacy development. Such support must address the specific requirements of academic language and literacy as students progress through school. It must address what Gibbons (2009, p. 141) refers to as "literate talk", as well as the specific register and genre demands of academic literacy in discipline-specific areas. As students work their way through school, they must be able to read texts where information and arguments are organised in ways that differ from spoken language, and they need insights into the increasingly abstract and 
metaphorical language of academic written texts (Christie \& Martin, 2007; Palincsar \& Schleppegrell, this issue; Wong Fillmore, this issue). They also need insights into ways in which language and literacy differ across different curriculum areas (Christie \& Derewianka, 2008). While many students from English-speaking backgrounds also require such support, the difference is that English-speaking-background students are able to build on a familiar oral language in their developing control of academic English while EAL students are not.

Anecdotal and research evidence in Australia and elsewhere indicates that there is widespread acknowledgement amongst teachers of the importance of language and literacy in learning (Jones \& Chen, 2012). However, there is also consistent evidence that they lack confidence in their knowledge of language and in their abilities to teach language and literacy in ways that provide necessary support for their students (Hammond, 2008; Macken-Horarik, Love, \& Unsworth, 2011). As one teacher from our research explained:

Most teachers don't have the skills to do that (i.e., teach more complex aspects of language) and I don't. I look at it (student's written text), I say, "You haven't expressed this very clearly". To pinpoint what they need to do is sometimes quite difficult, and it is very time-consuming.

The level of theoretical knowledge required for effective teaching of language and literacy is substantial. In Australia, systemic linguistics and the functional model of language have had a considerable, although uneven, impact on approaches to language and literacy education. Genre theory continues to have a major impact (although "text-types" is the preferred term in a number of Australian curriculum documents), and with it comes acknowledgement of the importance of teaching language and literacy across different levels of text structure, cohesion, grammar, and 
vocabulary. This impact is evident for example in content of the Australian Curriculum; English (ACARA, 2012b). Broadly, this theoretical orientation has shaped accepted understandings of the nature of language, including the relationship between text and context, and with this, acknowledgement that it is not possible to teach educational concepts without addressing the language that is required to engage with those concepts (Lemke, 1990; Coffin, 2006; Schleppegrell, 2004). Debates also continue in Australia, more generally, over the teaching of grammar. While there is broad acceptance of the importance of grammatical knowledge, there continues to be disagreement about which grammar and what level of detail is required (Derewianka, 2012).

\section{Illustrating Teaching of Language in the Science Classroom}

I return to the Year 6 science unit to illustrate ways in which the functional model of language impacted on program planning, and on specific teaching of language and literacy. Our focus was on ways of embedding deliberate and systematic teaching of language and literacy across the curriculum. The summary in Table 3 highlights relationships between the sequencing of classroom tasks and the language/literacy focus in sample tasks in the science unit.

Insert Table 3 here

Decisions as to which aspects of academic language and literacy should be included in the science program and at what points, were made in relation to the sequencing of tasks (designed to enable students to build the necessary scientific and language understandings as they worked towards completion of the Rich Task). Decisions were also informed by theoretical understandings of similarities and differences between spoken and written modes of language and of the linguistic demands of different kinds of tasks (Halliday, 1989). As the students progressed from 
one task to the next, the specific language demands shifted from primarily informal spoken interactions to more formal presentations. Concurrently, students engaged in activities that required more extended writing. By the time students were required to produce their own written explanations, they were familiar with key science concepts, they had appropriated the relevant scientific language, including technical scientific vocabulary, grammar of cause-and-effect sentences and text structure of explanations, that enabled them to discuss, read, and write about these concepts. The sequencing of tasks (mapped backward following analysis of the Rich Task demands) involved designed-in scaffolding to support students in their developing understanding of science concepts, and in their language and literacy development.

Sequencing of tasks in the Year 6 science program enabled students' language and literacy development to proceed in manageable and gradual steps. It also enabled the "design-in" of explicit teaching about language. As Table 3 shows, this included teaching about meanings of specific scientific terms; the grammar of cause-and-effect sentences; the structure and cohesion of explanations, including paragraph organisation; use of connectives; techniques for note-taking; research skills of finding specific information; skimming and scanning; reading for detail.

In sum, in their teaching of language and literacy, the knowledge required of teachers included:

- theoretical understanding of the nature of language and literacy (including theoretical understandings of the interrelationship between text and context, and implications of this relationship for students' developing control of discipline-specific academic registers);

- knowledge of different "text types" including their predictable patterns of text organisation, paragraph structure and cohesion; 
- knowledge of the relationship between spoken and written modes of language;

- knowledge of strategies for intensive and extensive reading;

- knowledge of grammar and of the kinds of grammatical features that characterise specific text types;

- knowledge of vocabulary, especially of technical vocabulary that facilitated understanding and discussion of specific scientific concepts;

- $\quad$ knowledge of the alphabet, spelling, and punctuation.

\section{Discussion: Teacher Knowledge and the Place of Standards}

This discussion of high-challenge, high-support programs for EAL students has attempted to provide some detail of the extent and complexity of knowledge teachers are required to draw upon in their work. The discussion suggests such knowledge must include at least: extensive discipline knowledge; knowledge of students and their language and literacy abilities; ability to undertake formative assessment of students; ability to analyse curriculum demands; knowledge of an extensive repertoire of teaching/pedagogical techniques; and the theoretical understandings of language, literacy, and learning that give depth and cohesion to the overall design of the program. In addition, it requires the ability to draw on all of the above to plan and implement programs in response to students' specific needs, in ways that challenge, engage, and inspire students, and enable them to envisage a future where they are successful learners (van Lier, 2004). The extent and complexity of the knowledge required of teachers is thus substantial.

Many of the details of the high-challenge, high-support classrooms in our research are likely to be familiar to people working within the field of TESOL and more broadly in language education. Thus decisions in program planning and 
implementation, described earlier, are likely to reflect those required of many teachers. The research, however, highlights two significant features.

Outcomes from our research confirm that EAL students can engage in high challenge programs, if they also have access to high levels of support. The outcomes therefore support previous evidence of the positive impact of high-challenge programs. More significantly, the research provides details of what such programs look like in practice, and it highlights tools that can assist teachers in the design and implementation of such programs. In doing so, it teases out the pedagogical implications of a strong sociocultural theoretical basis. The research also highlights the value of working both with sociocultural theories of learning and with systemic functional theory. As others have noted (Wells, 1999b; Gibbons, 2009), the intersection of these theoretical perspectives is a productive one that highlights the role of language in mediating learning. A contribution of the research is the insight it provides into what this looks like in practice. Teachers in our research reported that their theoretical understandings of learning and of language enabled them to select and sequence tasks to provide students with access to substantive curriculum knowledge, and with the levels of support they needed to engage with that knowledge. Thus, although individual tasks in their programs were not in themselves remarkable, for their EAL students it was the cumulative relationship between tasks that provided access to challenge and support that was remarkable.

I return now to the question of standards and their contribution to the education of EAL students. To what extent can standards documents address the breadth and depth of teacher knowledge highlighted in the discussion of our research?

Of the numerous standards in the Australian context, two most directly address the kind of teacher knowledge highlighted in the previous discussion: the 
Australian Curriculum, including the English discipline component; and the National Professional Standards for Teachers. These are particularly significant and relevant to teachers working with EAL students

As indicated, the Australian Curriculum emphasises equity and access for all students, and acknowledges the need for differentiated support for diverse groups of students. Thus it legitimizes programs characterised by high challenge and high support, and in this sense recognises the importance of teacher knowledge outlined in discussion of Dimensions 1 and 2. In addition, as indicated, the English document (ACARA, 2012b) is of particular relevance to EAL students and their teachers. It prioritises students' use of language and literacy, as well as knowledge about language and literacy. It has a theoretical cohesion that prioritises language and literacy and also provides detail of whole-text analysis, cohesion, sentence grammar, spelling, and phonics (Derewianka, 2012). Such detail is of real value to teachers working with EAL students and closely reflects the detailed knowledge addressed in discussion of Dimension 3. However, not all teachers are English teachers, and while Curriculum documents in other disciplines acknowledge the importance of language and literacy in learning, they provide little detail. For teachers who are already knowledgeable in theories and systems of language and who know how to embed language and literacy teaching with science, history, or other disciplines, there is a legitimate space for teaching language and literacy, but for teachers who lack knowledge and confidence in their ability to teach language and literacy, there is insufficient support to enable them to work effectively with their EAL students (Hammond, 2012).

As indicated, the National Professional Standards for Teachers address broad domains of knowledge required by teachers of EAL students, including recognition of 
the needs of diverse groups of learners and the need to provide differentiated and engaging learning strategies to meet these needs. Thus these Standards also legitimize relevant domains of knowledge outlined in Dimensions 1, 2 and 3, but provide insufficient detail to assist teachers who do not already have knowledge of these domains.

\section{Conclusions}

The discussion in this article has suggested that it is unrealistic and unproductive to rely on standards to address questions of teachers' knowledge in the kind of detail required to inform effective pedagogical practices, especially with EAL students. In addition, as discussion of the Australian context showed, standards may be overlapping, subject to political whim, and difficult to negotiate. I referred earlier to the notion of a strong pedagogical framework (Lo Bianco \& Freebody, 1997, p. 35 ), and in concluding this article I return to that notion.

The depth and breadth of knowledge required of teachers represents a lifelong learning pathway. Development of such knowledge requires rigorous teachereducation and professional-development programs where priority is given to thinking theoretically and pedagogically about curriculum content, about learning, about language and literacy, and about language development. Such thinking builds a principled pedagogical framework for ongoing and cumulative learning across a professional lifetime, and provides a rigorous basis that can inform teachers' decisions regarding effective pedagogical practices. While standards can be a powerful adjunct in providing legitimation of knowledge, they cannot and should not replace more-wide ranging, theoretically robust accounts of teacher learning and knowledge. 


\section{Acknowledgements}

I would like to thank Anne Burns for her very helpful feedback on an early draft of this article.

\section{The author}

Dr Jennifer Hammond is an associate professor and honorary associate in the Faculty of Arts and Social Sciences, University of Technology, Sydney. Her research interests are in literacy development; classroom interaction, and the implications of sociocultural and systemic theories of language and learning in ESL and refugee education.

\section{References}

Australian Council of TESOL Associations (ACTA). (2004). Professional teaching standards: language and culture components for teachers of ESL learners. Retrieved from www.tesol.org.au.

Australian Council of TESOL Associations (ACTA). (2013). EAL/D standards elaboration. Retrieved from www.tesol.org.au.

Australian Curriculum Assessment and Reporting Authority (ACARA, formerly National Curriculum Board). (2009). The shape of the Australian Curriculum. Version 2.0. Retrieved from www.acara.edu.au.

Australian Curriculum Assessment and Reporting Authority (ACARA). (2011). English as an additional language or dialect: Teacher resource. Version 1.2. Retrieved from www.acara.edu.au.

Australian Curriculum Assessment and Reporting Authority (ACARA) (2012a). The Australian Curriculum. Retrieved from www.australiancurriculum.edu.au. 
Australian Curriculum Assessment and Reporting Authority (ACARA). (2012b). The Australian Curriculum: English. Retrieved from www.australiancurriculum.edu.au/English/Curriculum/F-10.

Australian Institute for Teaching and School Leadership (AITSL). (2011). National Professional Standards for Teachers. Retrieved from www.aitsl.edu.au.

Australian Qualifications Framework Council. (2013). Australian Qualifications Framework (second edition). Retrieved from www.aqf.edu.au.

Barnett, J. (2012, November). Update on National Professional Standards for Teachers: The place of EAL students. Oral presentation at South Australian TESOL Conference, Adelaide.

Bunch, G. C. (2013). Pedagogical language knowledge: Preparing mainstream- teachers for English Learners in the New Standards Era. AERA Review of Research in Education, 37, 298-341. doi: 10.3102/0091732X12461772

Centre for Education, Statistics and Evaluation. (2012). Language Diversity in NSW government schools in 2012. CESE Bulletin Issue 1. NSW Department of Education and Communities.

Christie, F., \& Derewianka, B. (2008). School discourse: Learning to write across the years of schooling. London: Continuum.

Christie, F., \& Martin, J. (2007). Language, knowledge and pedagogy: Functional linguistics and sociological perspectives. London: Continuum.

Coffin, C. (2006). Historical discourse: The language of time, cause and evaluation. London: Continuum.

Cummins, J. (2000). Language, power and pedagogy: Bilingual children in the cross-fire. Clevedon: Multilingual Matters.

Curriculum Corporation. (1994). ESL Scales, Melbourne: Curriculum Corporation. 
Derewianka, B. (2012). Knowledge about language in the Australian Curriculum: English. Australian Journal of Language and Literacy, 35(2), 127-146.

Flores, N. \& Schissel, J. (this issue). Dynamic bilingualism as the norm: Envisioning a heteroglossic approach to standards-based reform.

Freeman, D. (2002). The hidden side of the work: Teaching knowledge and learning to teach. A perspective from North American educational research on teacher education in English language teaching. Language Teaching, 35, 1-13. doi:

$10.1017 / \mathrm{S} 0261444801001720$

Gibbons, P. (2002). Scaffolding language, scaffolding learning: Teaching ESL children in the mainstream classroom. Portsmouth, NH: Heinemann.

Gibbons, P. (2008). "It was taught good and I learned a lot": Intellectual practices and ESL learners in the middle years. Australian Journal of Language and Literacy, 31(2), $155-173$

Gibbons, P. (2009). Challenging expectations: Literacy, intellectual quality and English language learners in the middle years. Portsmouth NH: Heinemann.

Halliday, M.A.K. (1978). Language as social semiotic: The social interpretation of language and meaning. London: Edward Arnold.

Halliday M.A.K. (1989). Spoken and written language. New York: Oxford University Press.

Hammond, J (2008). Intellectual challenge and ESL students: Implications of quality teaching initiatives. Australian Journal of Language and Literacy, 31(2), 128-154.

Hammond, J. (2012). Hope and challenge in the Australian Curriculum: Implications for EAL students and their teachers. Australian Journal of Language and Literacy, 35(2), 223-240.

Hammond, J., \& Gibbons, P. (2005). Putting scaffolding to work: The contribution of scaffolding in articulating ESL education. Prospect, (20(1), 6-30. 
Johnston, K., \& Hayes, D. (2008). 'This is as good as it gets': Classroom lessons and learning in challenging circumstances. Australian Journal of Language and Literacy, 31, 2, 109-127.

Jones, P., \& Chen, H. (2012). Teachers' knowledge about language: Issues of pedagogy and expertise. Australian Journal of Language and Literacy, 35(2), 147-168.

Koelsch , N., Chu, H., \& Rodriguez Banuelos, G. et al (this issue). Language for learning: Supporting English language learners tot meet the challenges of new standards.

Lemke, J. (1990). Talking science: Language, learning and values. Norwood, NJ: Ablex Publishing.

Lo Bianco, J., \& Freebody, P. (1997). Australian Literacies: Informing national policy on literacy education. Canberra, Commonwealth of Australia.

Macken-Horarik, M., Love, K., \& Unsworth, L. (2011). Grammatics good enough for school English in the 21st Century. Australian Journal of Language and Literacy, 34(2), 923.

Mehan, H. (1992). Understanding inequality in school: The contribution of interpretive studies. Sociology of Education, 65, 1-20.

Mercer, N. (1994). Neo-Vygotskian theory and classroom education. In B. Steiner \& J. Maybin (Eds.), Language, literacy and learning in educational practice, (pp. 92-110). Clevedon: Multilingual Matters.

Michell, M., \& Sharpe, T. (2005). Collective instructional scaffolding in English as a Second Language Classrooms. Prospect, 20(1), 31-58.

National Assessment Program - Literacy and Numeracy (NAPLAN). (2011). Retrieved from www.naplan.edu.au.

Palincsar, A. S., \& Schleppegrell, M. (this issue). Focusing on language and meaning while learning with text. 
The New Basics Project. (2001). New Basics: The Why, What, How and When of Rich Tasks. Education Queensland, Queensland State Education.

Newmann, F. M., Marks, H., \& Gamoran, A. (1996). Authentic pedagogy and student performance. American Journal of Education, 104, 280-312. doi: 10.1086/444136

Nunan, D. (2007). Standards-based approaches to the evaluation of ESL instruction. International Handbook of English Language Teaching. Springer International Handbooks of Education, 15, 421-438. doi: 10.1007/978-0-387-46301-8_31

Productive Pedagogies Classroom Observation Manual (2002). Curriculum Innovation Branch, Education Queensland.

Quality Teaching in NSW Public schools: Discussion paper. (2003). Professional Support and Curriculum Directorate, NSW Department of Education and Training.

Schleppegrell, M. (2004). The language of schooling: A functional linguistics perspective. Mahwah, NJ: Erlbaum.

Shulman, L. S. (1987). Knowledge and teaching: Foundations of the new reform. Harvard Educational Review 57(1), 1-21.

Thompson, S., de Bortoli, L., \& Buckley, S. (2013). PISA 2012: How Australia measures up. Camberwell: Australian Council for Educational Research.

van Lier, L. (1996). Interaction in the language curriculum: Awareness, autonomy and authenticity. London: Longman.

van Lier, L. (2004). The ecology and semiotics of language learning: A sociocultural perspective. Dordrecht: Kluwer.

Verplaetse, L. S. (this issue)

Vygotsky, L. (1978). Mind in society: The development of higher psychological processes. M. Cole, V. John-Steiner, S. Scribner, \& E. Souberman (Eds.). Cambridge MA: Harvard University Press. 
Wells, G. (1999a). Language and education: Reconceptualizing education as dialogue. Annual Review of Applied Linguistics, 19, 135-155. doi:

\section{$10.1017 / \mathrm{S} 026719059919007 \mathrm{X}$}

Wells, G. (1999b). Dialogic inquiry: Towards a sociocultural practice and theory of education. Cambridge: Cambridge University Press.

Wiggins, G., \& McTighe, J. (2005). Understanding by design (expanded $2^{\text {nd }}$ edition).

Alexandria, VA: Association for Supervision and Curriculum Development (ASCD).

Wong Fillmore, L. (this issue). English learners at the crossroads of educational reform. 


\section{Table 1: Examples of Essential Questions and Rich Tasks}

Year 6 Unit on vision:

Essential Questions
Year 7 Unit on Matter:

Essential questions
Key concepts

- What are the basic properties of light and the relationship of light to eyesight?

- What are the parts and functions of human and animal eyes?

Relevance

- How can an understanding of light help us understand what it would be like to be blind or have a visual impairment?

- What ethical issues to do with blindness and inequalities exist for visually impaired people?
Key concepts

- What are the basic elements of the earth?

- How do we classify matter?

- How do scientists classify matter?

Relevance

- What are the practical implications/applications of knowledge of elements, compounds and mixtures?

- Why do we learn about matter?

- How can knowledge of elements of the world be of use beyond school?

\section{Year 6 Rich Task}

The task: to undertake group research to answer the following questions:

- What is the nature and what are the implications of one type of visual impairment?

Procedure: oral explanation to be presented to your class, followed by written explanation.

- What are some of the ethical issues that arise in funding of programs addressing visual impairment (such as the Fred Hollows ${ }^{1}$ program)?

Procedure: oral and then written exposition.

\section{Year 7 Rich Task}

The task: to undertake group research to discover who "polluted" ${ }^{2}$ Ropes River (a local river near the school)?

- Use your knowledge of scientific procedures and analysis to identify the possible culprit of the pollution in Ropes River.

Procedures to use in research

- Comparisons of polluted and unpolluted water;

- Group experiments: filtration; decanting; crystallisation; magnetic separation;

- Draw on scientific evidence to work out the nature of the pollution and then decide who could have been the possible culprit;

- Write a group report based on science experiments and evidence.

1 The late Dr Fred Hollows, an Australian ophthalmologist, established a foundation that remains active in providing cost-effective programs for treating visual impairments in developing countries.

2 The "pollution" was simulated by teachers who prepared samples of river water for the purposes of the Rich Task. 


\section{Table 2: Example of Tasks and Message Abundancy}

Task

Message Abundancy

\begin{tabular}{|c|c|}
\hline $\begin{array}{l}\text { Group experiments on light and } \\
\text { visual impairment (experiments } \\
\text { simulated various visual } \\
\text { impairments). }\end{array}$ & $\begin{array}{l}\text { Physical manipulation of objects; peer } \\
\text { discussion; teacher talk to support } \\
\text { students' action in experiments; pro- } \\
\text { forma for students to record/ write } \\
\text { outcomes of experiments. }\end{array}$ \\
\hline $\begin{array}{l}\text { Oral reconstruction of procedures } \\
\text { and outcomes of experiments } \\
\text { (whole-class activity with } \\
\text { individual contributions). }\end{array}$ & $\begin{array}{l}\text { Wall charts with definitions of key } \\
\text { terms; teacher blackboard work to } \\
\text { summarise students' contributions; } \\
\text { teacher mediation to support students' } \\
\text { oral reconstructions. }\end{array}$ \\
\hline $\begin{array}{l}\text { Group library research: } \\
\text { information about specific visual } \\
\text { impairments; agreement on key } \\
\text { points; summary notes. }\end{array}$ & $\begin{array}{l}\text { Librarian support; books; videos; } \\
\text { internet; locating sources of information; } \\
\text { reading; peer discussions; pro-forma for } \\
\text { writing notes. }\end{array}$ \\
\hline $\begin{array}{l}\text { Consolidating understanding of } \\
\text { selected visual impairment; } \\
\text { teacher support in group } \\
\text { discussions; organisation of } \\
\text { information in preparation for } \\
\text { oral presentations. }\end{array}$ & $\begin{array}{l}\text { Teacher explanation; notes from pro- } \\
\text { forma; wall charts and diagrams; new } \\
\text { pro-forma to support preparation of } \\
\text { forthcoming presentations. }\end{array}$ \\
\hline $\begin{array}{l}\text { Oral explanations to class - } \\
\text { group presentations. }\end{array}$ & $\begin{array}{l}\text { Students' oral explanations; supporting } \\
\text { visual charts; graphs. }\end{array}$ \\
\hline $\begin{array}{l}\text { Negotiation in groups of } \\
\text { questions for forthcoming visiting } \\
\text { speaker (who had a visual } \\
\text { impairment); whole class } \\
\text { agreement on questions. }\end{array}$ & $\begin{array}{l}\text { Teacher suggestions; peer discussion; } \\
\text { notes, wall charts; diagrams; etc. }\end{array}$ \\
\hline $\begin{array}{l}\text { Whole-class review of structure } \\
\text { and language features of text } \\
\text { type: explanations. }\end{array}$ & $\begin{array}{l}\text { Model of text type (wall chart showing } \\
\text { key features); teacher and student } \\
\text { discussion. }\end{array}$ \\
\hline $\begin{array}{l}\text { Group preparation for writing of } \\
\text { explanations: building on library } \\
\text { research + knowledge of structure } \\
\text { of explanations; initial draft. }\end{array}$ & $\begin{array}{l}\text { Peer discussion; reference to model; } \\
\text { reading of notes; writing. }\end{array}$ \\
\hline
\end{tabular}




\section{Table 3: Classroom tasks and language/literacy focus}

\section{Classroom task + language demands}

Teaching of language

(implicit and explicit)

\begin{tabular}{|l|l|}
\hline $\begin{array}{l}\text { Group experiments: } \\
\text { context embedded task; language } \\
\text { accompanying action; brief written } \\
\text { notes. }\end{array}$ & $\begin{array}{l}\text { Teacher modelling of new scientific vocabulary (+ } \\
\text { reference to wall charts that listed and explained } \\
\text { scientific terms); teacher mediation of written } \\
\text { responses to pro-forma. }\end{array}$ \\
\hline $\begin{array}{l}\text { Reconstruction of experiments: } \\
\text { language used to reconstruct processes } \\
\text { and outcomes of experiments. }\end{array}$ & $\begin{array}{l}\text { Teacher support to sequence events; modelling of } \\
\text { grammar of cause and effect in sentences + } \\
\text { subsequent explicit focus on grammar of cause and } \\
\text { effect. }\end{array}$ \\
\hline $\begin{array}{l}\text { Library research: } \\
\text { reading; peer discussion; written note } \\
\text { taking. }\end{array}$ & $\begin{array}{l}\text { Reminder (by librarian) and explicit discussion of } \\
\text { research skills of finding specific information; } \\
\text { skimming and scanning; reading for detail. }\end{array}$ \\
\hline $\begin{array}{l}\text { Group discussion of visual impairment } \\
\text { / preparing oral explanations: } \\
\text { peer discussions; teacher support with } \\
\text { use of cause and effect sentences. }\end{array}$ & $\begin{array}{l}\text { Reminder of grammar of cause and effect; reminder } \\
\text { of text structure and language features of oral } \\
\text { presentations (including reference to a wall chart } \\
\text { that summarised these features). }\end{array}$ \\
\hline $\begin{array}{l}\text { Presenting oral explanations to class: } \\
\text { extended explanations of visual } \\
\text { impairment. }\end{array}$ & $\begin{array}{l}\text { Further review of structure and language features of } \\
\text { oral explanations (through whole class analysis of } \\
\text { strengths and any possible areas for improvement of } \\
\text { students' group presentations). }\end{array}$ \\
\hline
\end{tabular}

